\title{
Suppressive Effects of Tranilast on Pulmonary Fibrosis and Activation of Alveolar Macrophages in Mice Treated with Bleomycin: Role of Alveolar Macrophages in the Fibrosis
}

\author{
Hiroshi Mori ${ }^{1}$, Hiroyuki Tanaka ${ }^{1}$, Kenji Kawada ${ }^{2}$, Hiroichi Nagai $^{1}$ and Akihide Koda ${ }^{1}$ \\ 'Department of Pharmacology, Gifu Pharmacewical University, 5-6-1, Mitahora-higashi, Gifu 502, Japan \\ ${ }^{2}$ Gifu College of Medical Technology, 795-1, Nagamine, Ichihiraga, Seki 501-32, Japan
}

Received July 29, 1994 Accepted January 4, 1995

\begin{abstract}
We have reported that tranilast, an anti-allergic drug that inhibits chemical mediator release from mast cells, suppresses bleomycin (BLM)-induced pulmonary fibrosis in mice through mechanisms other than inhibiting chemical mediator release from mast cells. The purpose of this paper is to examine the effect of tranilast on alveolar macrophage (AM) activation and on the development of fibrosis in ICR mice instilled with BLM intratracheally. Twenty eight days after the BLM instillation $(0.01 \mathrm{mg} / \mathrm{mouse})$, AM often migrated into alveolar spaces surrounding the fibrotic areas. Flow cytometry analysis for the size and density of AM (MAC-1 positive cells) suggested that AM were activated not only in the earlier acute inflammatory phase, but also in the later chronic phase. The p.o. administration of tranilast suppressed an increase of AM activity to produce reactive oxygen species in BLM-instilled mice, and it inhibited the subsequent development of pulmonary fibrosis. In vitro treatment with tranilast suppressed the reactive oxygen species production from murine peritoneal macrophages. However, several different anti-oxidants failed to inhibit the development of fibrosis. These results suggest that the activation of AM plays an important role in the development of fibrosis, and it is likely that tranilast suppresses fibrosis by inhibiting AM activation but not by scavenging reactive oxygen species.
\end{abstract}

Keywords: Pulmonary fibrosis, Bleomycin, Tranilast, Alveolar macrophage, Reactive oxygen species

Interstitial pulmonary fibrosis is a potentially lethal and chronic response of the lung to injury. Regardless of the cause for the injury, interstitial pulmonary fibrosis is invariably accompanied by excessive remodeling processes.

BLM represents a group of glycopeptides that are used in cancer chemotherapy (1). The use of BLM as an antineoplastic drug is limited, however, because it produces a dose-dependent pneumonitis that often progresses to interstitial pulmonary fibrosis in humans (1). BLM-induced experimental pulmonary fibrosis in rodents is often used as an animal model for interstitial pulmonary fibrosis, because its pathophysiology resembles that seen in humans $(2,3)$.

Tranilast has long been used clinically to treat allergic diseases such as bronchial asthma, atopic dermatitis and allergic rhinitis. The efficacy of tranilast in the treatment of these allergic diseases is based on the inhibition of antigen-induced chemical mediator release from mast cells and basophils (4-6). Previously we reported that tranilast suppressed BLM-induced pulmonary fibrosis in WBB6 $\mathrm{F}_{1}-\mathrm{W} / \mathrm{W}^{v}$ mice and ICR mice $(7,8)$. These findings indicate that mast cells do not play an essential role in the development of fibrosis and that tranilast suppresses fibrosis through mechanisms other than the inhibition of chemical mediator release from mast cells.

There are many reports $(9-11)$ describing an increase in the number of $\mathrm{AM}$ associated with the development of fibrosis in humans and animal models including BLM-induced fibrosis. It is known that AM have numerous physiological/immunological functions, not only for protec-

Abbreviations used are: BLM, bleomycin hydrochloride; AM, alveolar macrophages; IL, interleukin; PDGF, platelet-derived growth factor; TNF, tumor necrosis factor; TGF, transforming growth factor; PBS, phosphate-buffered saline; DMSO, dimethyl sulfoxide; Vt-E, vitamine E; DMTU, dimethyl thiourea; HP, hydroxyproline; BALF, bronchoalveolar lavege fluid; HE, hematoxylin-eosin; FCS, fetal calf serum; FSC, forward scatter; SSC, side scatter; HBSS, Hanks' balanced salt solution; HRPO, horseradish peroxidase; PMA, phorbol myristate acetate; PEC, peritoneal exudate cells. 
tion from foreign substances such as microorganisms but also for promoting inflammation. It is also well established that AM produce several cytokines, including IL-1, PDGF, TNF- $\alpha$, TGF- $\beta$ and proteins including fibronectin (12). It is claimed that IL-1 (13), PDGF (14), TNF (15) and TGF- $\beta$ (16) derived from AM up-regulate fibroblast proliferation and collagen production during the course of lung fibrosis. Thus, AM may be involved in the development of pulmonary fibrosis.

Recently, it has been reported that tranilast suppresses mitogen-induced activation of lymphocytes, IL-1 production from macrophages, IL-1 dependent fibroblast proliferation, IL-2 production from T cells and IL-2 dependent proliferation of lymphocytes (17) and that tranilast suppresses the production of superoxide anion from human neutrophils (5). These findings suggest that tranilast suppresses not only the activation of mast cells but also those of monocytes, lymphocytes and leukocytes. It has also been reported that tranilast scavenges superoxide anions produced in the cell-free xanthinexanthine oxidase in vitro system (18).

The purpose of this paper is, therefore, to examine the effect of tranilast on AM activation and development of pulmonary fibrosis in mice instilled with BLM intratracheally. This will help to elucidate the role of the activated AM in BLM-induced fibrosis.

\section{MATERIALS AND METHODS}

\section{Animals}

ICR female mice were purchased from Japan SLC (Hamamatsu) and maintained with free access to pellet food and water in filtered laminar air flow cages at $22 \pm 1{ }^{\circ} \mathrm{C}$ and $60 \pm 5 \%$ relative humidity. Intratracheal instillation of BLM was carried out when the mice were 15-week-old. In the other experiments, mice were used at 7- to 10 -week-old.

\section{Drugs}

BLM (Nipponkayaku Co., Tokyo) was dissolved in sterilized saline. Tranilast (Kissei Pharmaceutical Industries, Ltd., Matsumoto) was dissolved in a small amount of water containing $0.5 \% \mathrm{NaHCO}_{3}$ and added to PBS (pH 7.4) to give a 6-mM solution for the in vitro study. For the in vivo study, tranilast was dissolved in water containing $0.5 \% \mathrm{NaHCO}_{3}$. DMSO (Nacalai Tesque, Kyoto) and Vt-E $(\alpha-( \pm)$-tocopherol acetate; Sigma Chemical Company, St. Louis, MO, USA) were dissolved in olive oil. KB-5666 donated by Kanebo Co., Ltd. (Osaka) and DMTU (Sigma Chemical Company) were dissolved in water. CV-3611 donated by Takeda Chemical Industries, Ltd. (Osaka) was suspended in water containing $0.5 \%$ Arabia gum. Allopurinol (Sigma Chemical Company) was suspended in water containing $0.1 \%$ carboxy methyl cellulose-Na. The agents were given to mice per orally (p.o.) or intraperitoneally (i.p.) at a volume of $0.1 \mathrm{ml} / 10$ $\mathrm{g}$ body weight.

\section{Induction of pulmonary fibrosis}

BLM was intratracheally instilled into 15-week-old ICR female mice at a dose of $0.01 \mathrm{mg} / 0.1 \mathrm{ml}$. They were killed by bleeding under ether anesthesia. The right lungs were used for measuring HP content, and the left lungs were used for histological examination. In some experiments, intraparenchymal lung cells or BALF were prepared from the mice.

\section{HP content}

The lung was weighed (wet weight) and the right lung was cut into sections (1-mm-thick) with a tissue chopper (Micklel Laboratory Engineering, Gomshall, UK). The chopped lung was dried with acetone $(10 \mathrm{ml}$ per day for 4 days, for a total of $40 \mathrm{ml}$ ) and weighed (dry weight). The dried lung samples were hydrolyzed with $2 \mathrm{ml}$ of $6 \mathrm{~N} \mathrm{HCl}$ at $120^{\circ} \mathrm{C}$ for $24 \mathrm{hr}$ in tightly capped tubes. The amount of HP in the hydrolysate was measured according to Kivirikko et al. (19). Authentic HP was used to establish a standard curve.

\section{Histological examination of the lung}

The left lung was infiltrated with $10 \%$ buffered formalin through the cannulated trachea at a pressure of $10-12$ $\mathrm{cmH}_{2} \mathrm{O}$ and fixed for 24 to $48 \mathrm{hr}$ in the fixative solution. The fixed lung was cut into five parasagittal blocks covering virtually the whole lung. Histological sections $(3 \mu \mathrm{m})$ were obtained from each block after embedding in paraffin. HE staining and Azan-Mallory staining were carried out on the sections.

\section{Preparation of intraparenchymal lung cells}

Intraparenchymal lung cells were prepared according to the method of Abraham et al. (20). Briefly, mice were killed by bleeding under ether anesthesia, and the chest was opened. The lung vascular bed was flashed by injecting $10 \mathrm{ml}$ of chilled calcium, magnesium and phenolphthalein-free PBS $(-)$ containing $5 \mathrm{U} / \mathrm{ml}$ heparin into the right ventricle. The lungs were minced finely and incubated in RPMI-1640 containing 5\% FCS, $20 \mathrm{U} / \mathrm{ml}$ collagenase (Wako Pure Chemical Industries, Ltd., Osaka) and $1 \mu \mathrm{g} / \mathrm{ml}$ DNase (Type I; Calbiochem Corp., San Diego, CA, USA). A total volume of $10 \mathrm{ml}$ was used for each set of lungs. After incubation for $60 \mathrm{~min}$ at $37^{\circ} \mathrm{C}$, tissue fragments were removed by rapid filtration through nylon meshes, and the cells were collected by centrifugation at $150 \times g$ for $10 \mathrm{~min}$ at $4^{\circ} \mathrm{C}$. The erythrocytes in the cells were removed by treating with tris- $\mathrm{HCl}$ buffered solu- 
tion (pH 7.6) containing $0.75 \% \mathrm{NH}_{4} \mathrm{Cl}$ and washing twice with PBS $(-)$ containing $0.1 \%$ bovine serum albumin (Wako Pure Chemical Industries). Thus, $10^{6}-10^{7}$ intraparenchymal lung cells were obtained from each set of mouse lungs and used for flow cytometry analysis.

\section{Analysis of AM in intraparenchymal lung cells by flow cytometry}

Intraparenchymal lung cells were stained with FITClabeled rat anti-mouse macrophage (MAC-1) antibody (Macrph-FITC, M1/70.15; Coulter Immunology, Hialeah, FL, USA). A million cells were incubated with $10, \mu$ of the antibody preparation for $30 \mathrm{~min}$ at $4{ }^{\circ} \mathrm{C}$. Then the cells were washed three times with $\operatorname{PBS}(-)$ containing $0.1 \% \mathrm{NaN}_{3}$. Multiparameter flow cytometry was carried out using a FACS can II analyzer (Beckton Dickinson Immunocytometry System, San Jose, CA, USA), and the data $(10,000$ events/sample) were processed using the LYSIS II program (Beckton Dickinson Immunocytometry System). FITC (fluorescence 1 channel)-positive cells were gated as the Mac-1 positive cell population. Propiodium iodide (fluorescence 3 channel)-positive cells were gated out as dead cells. Then the size and density of Mac1 positive cells (AM) were analyzed against FSC and SSC parameters. The cells not treated with the antibody were used as a negative control to the sample from each of the mice.

\section{Preparation of $A M$ from $B A L F$}

Mice were killed by bleeding under anesthesia with an i.p. injection of pentobarbital sodium $(50 \mathrm{mg} / \mathrm{kg})$. The BALF was obtained by gently repeated cycles of infusing and withdrawing of Tris-HCl-buffered saline (pH 7.4) containing $0.4 \mathrm{mM}$ ethylenediamine tetraacetate disodium through the cannulated trachea. The BALF samples obtained from more than 13 mice/group were pooled in a plastic tube cooled on ice and then centrifuged at $150 \times \mathrm{g}$ for $10 \mathrm{~min}$ at $4^{\circ} \mathrm{C}$. The cells were resuspended in HBSS and the adherent cells (AM) were separated as described above. The AM obtained were used for the hydrogen peroxide production assay.

\section{Hydrogen peroxide production assay}

Hydrogen peroxide produced from peritoneal macrophages or AM was measured according to the method of Pick and Mizel (21). This method is based on the $\mathrm{H}_{2} \mathrm{O}_{2}$ dependent oxidization of phenol red in the presence of HRPO. Briefly, $40 \mu l$ of the AM or the peritoneal macrophage suspension $\left(2.5 \times 10^{6} \mathrm{cells} / \mathrm{ml}\right)$ was placed into a well of 96-well, flat-bottomed tissue culture plates and incubated for $60 \mathrm{~min}$ at $37^{\circ} \mathrm{C}$. The plates were washed with warmed $\left(37^{\circ} \mathrm{C}\right.$ ) PBS containing $5.5 \mathrm{mM}$ dextrose (dextrose-PBS, $\mathrm{pH}$ 7.4). Then the buffer for the cells was replaced with $60 \mu 1$ of assaying buffer (dextrose-PBS containing $190 \mathrm{U} / \mathrm{ml}$ of HRPO (Sigma), $300 \mathrm{U} / \mathrm{ml}$ of superoxide dismutase (Sigma) and $0.56 \mathrm{mM}$ phenol red). After incubation at $37^{\circ} \mathrm{C}$ for $90 \mathrm{~min}, 10 \mu \mathrm{l}$ of $1 \mathrm{~N} \mathrm{NaOH}$ was added to each well, and the optical density at $620 \mathrm{~nm}$ was measured. The amount of the reactive oxygen species produced was calculated from the standard curve established using $\mathrm{H}_{2} \mathrm{O}_{2}$ solution of a defined concentration. The data are shown as nanomole $\mathrm{H}_{2} \mathrm{O}_{2}$ per $1 \times 10^{5}$ cells per well.

When stimulating the cells with $200 \mathrm{nM}$ PMA or 1 $\mathrm{mg} / \mathrm{ml}$ of opsonized zymosan, the stimulators were mixed with the assaying buffer and applied to the cells. The opsonized zymosan was prepared as follows: Zymosan A (Sigma) was suspended at a concentration of $5 \mathrm{mg} / \mathrm{ml}$ in water and heated for $2 \mathrm{hr}$ at $200^{\circ} \mathrm{C}$, and then it was stored at $4{ }^{\circ} \mathrm{C}$. The stored zymosan was washed with gelatin veronal buffer containing $0.15 \mathrm{mM} \mathrm{Ca}^{2+}$ and $0.5 \mathrm{mM}$ $\mathrm{Mg}^{2+}\left(\mathrm{GVB}^{-1}\right)$ by centrifugation ( $200 \mathrm{rpm}, 4^{\circ} \mathrm{C}, 10 \mathrm{~min}$ ). The precipitate was resuspended into fresh ICR mice serum at $1 / 10$ of the volume of the suspension used for storage, and it was then incubated for $30 \mathrm{~min}$ at $37^{\circ} \mathrm{C}$. The particles were then washed with dextrose-PBS. When stimulated with the opsonized zymosan, $2 \mathrm{mM} \mathrm{CaCl}_{2}$ was supplemented further to the assaying buffer.

\section{Preparation of peritoneal macrophages}

Mice were injected i.p. with $3 \mathrm{ml}$ of thioglycollate medium. Three days later, PEC were collected by washing the peritoneal cavity twice with $3 \mathrm{ml}$ of HBSS. PEC were washed with HBSS three times and suspended in $7-8 \mathrm{ml}$ of Dulbecco's modified Eagle medium containing 10\% FCS. The adherent cells were separated by the usual method. Briefly, the PEC suspension was added to a plastic dish ( $9 \mathrm{~cm}$ in diameter) that had been coated with FCS and incubated for 30-60 min. After the removal of nonadherent cells by vigorous shaking, the adherent cells were harvested as peritoneal macrophages and used for the hydrogen peroxide production assay.

\section{Statistical analyses}

Data are represented as the mean \pm S.E.M. The significance of difference between 2 groups was analyzed by Student's or Welch's two tailed $t$-test after the $F$-test to examine the homogeneity of the difference between the two groups. A value of $\mathrm{P}<0.05$ was considered a significant difference.

\section{RESULTS}

Time course of fibrosis development and histological changes in lung of mice after BLM instillation

The intratracheal instillation of BLM increased, after 7 


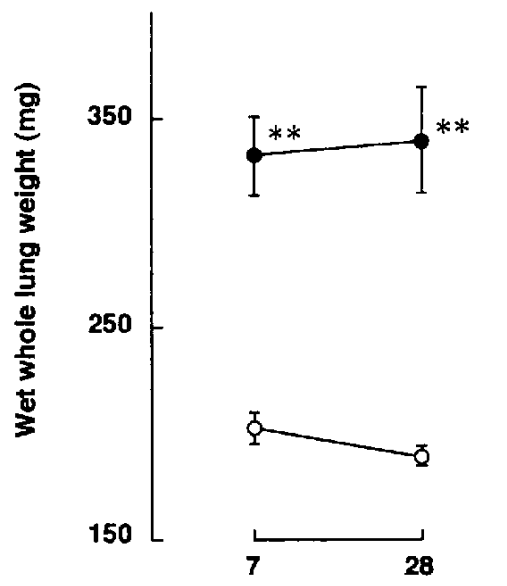

Days after the BLM-treatment
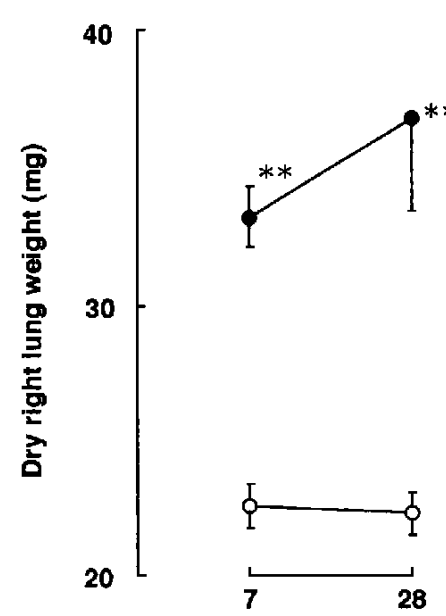

Days after the BLM-treatment

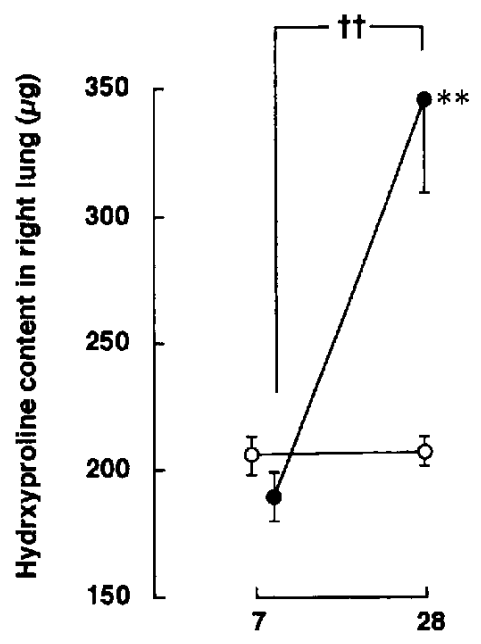

Days after the BLM-treatment

Fig. 1. Lung weight and hydroxyproline content in the lung of ICR mice instilled with bleomycin (BLM) intratracheally. Mice were given BLM at a dose of $0.01 \mathrm{mg} /$ mouse on day 0 . Each point represents the mean \pm S.E.M. of 7 to 8 mice. ${ }^{* *}$ : Statistically significant difference from the corresponding saline group at $\mathbf{P}<0.01{ }^{\text {t+ }}$ : Statistically significant difference between data on days 7 and 28 of BLM-instilled mice at $\mathrm{P}<0.01$.

and 28 days, the wet and dry lung weights significantly compared with those of mice that received an intratracheal instillation of saline (Fig. 1). The HP content of the lung in the mice instilled with BLM showed no change on day 7 , but increased significantly on day 28 compared with that of the saline group (Fig. 1).

In the histopathological examination (Fig. 2), the saline-instilled mice showed no visible lesions, and their intraalveolar septa had a normal thin appearance on both days 7 and 28 (picture not shown). In contrast, 7 days after the instillation of BLM, acute type inflammation was observed; perivascular edema, intraalveolar edema, lymphatic cell infiltration and a great increase in the number of AM were observed. Fibrotic change was not yet visible. Twenty-eight days after BLM instillation, fibrotic changes were clearly observed but edema was not. Most of the lung area had thickened septa. In those fibrotic lesions having a collagenous matrix, lymphocytes frequently aggregated nodularly, and a small number of plasma cells sometimes infiltrated around these lymphoid cell clusters. AM with foamy changes often migrated into alveolar spaces surrounding the fibrotic areas, especially in the subpleural regions. Neutrophils were less common as cellular elements infiltrated. Edema on day 7 and fibrosis on day 28 were observed mainly in the subpleural regions.

Time course of changes in flow cytometry-analyzed size and density of intraparenchymal AM after BLM instillation

Figure 3 shows representative plot patterns of the comparative distribution of FSC and SSC of intraparen- chymal AM obtained 18 days after the intratracheal instillation of saline or BLM. The instillation of BLM shifted the distribution to the upper-right compared with that seen after saline instillation.

Figure 4 shows changes in the mean FSC value and mean SSC value of the AM following the instillation. In mice instilled with saline, the FSC value increased on day 6 and the SSC value on day 12. Compared with that of the cells obtained from saline-instilled mice, the FSC value of the cells obtained from BLM-instilled mice increased significantly on day 18 . The SSC value tended to increase day by day after BLM instillation, although the value of the cells from saline-instilled mice on day 12 was higher than that of the cells from BLM-instilled mice.

Time course of changes in activity of $A M$ to produce hydrogen peroxide after BLM instillation and effect of tranilast on it

AM was obtained from the BALF of mice on various days after the BLM instillation. In the control mice instilled with BLM, the hydrogen peroxide production from the PMA-stimulated AM increased markedly on day 6 . It tended to show a greater increase on days 12,18 and 24 compared with that of the AM obtained from normal mice, which is indicated as the value on day 0 in Fig. 5. Hydrogen peroxide production from the non PMA-stimulated cells (PMA $(-)$ ) also tended to show an increase on days 18 and 24, although the amount of produced hydrogen peroxide was quite low throughout the experimental period compared with that produced from PMA-stimulated cells. Tranilast $(20 \mathrm{mg} / \mathrm{kg})$ was 

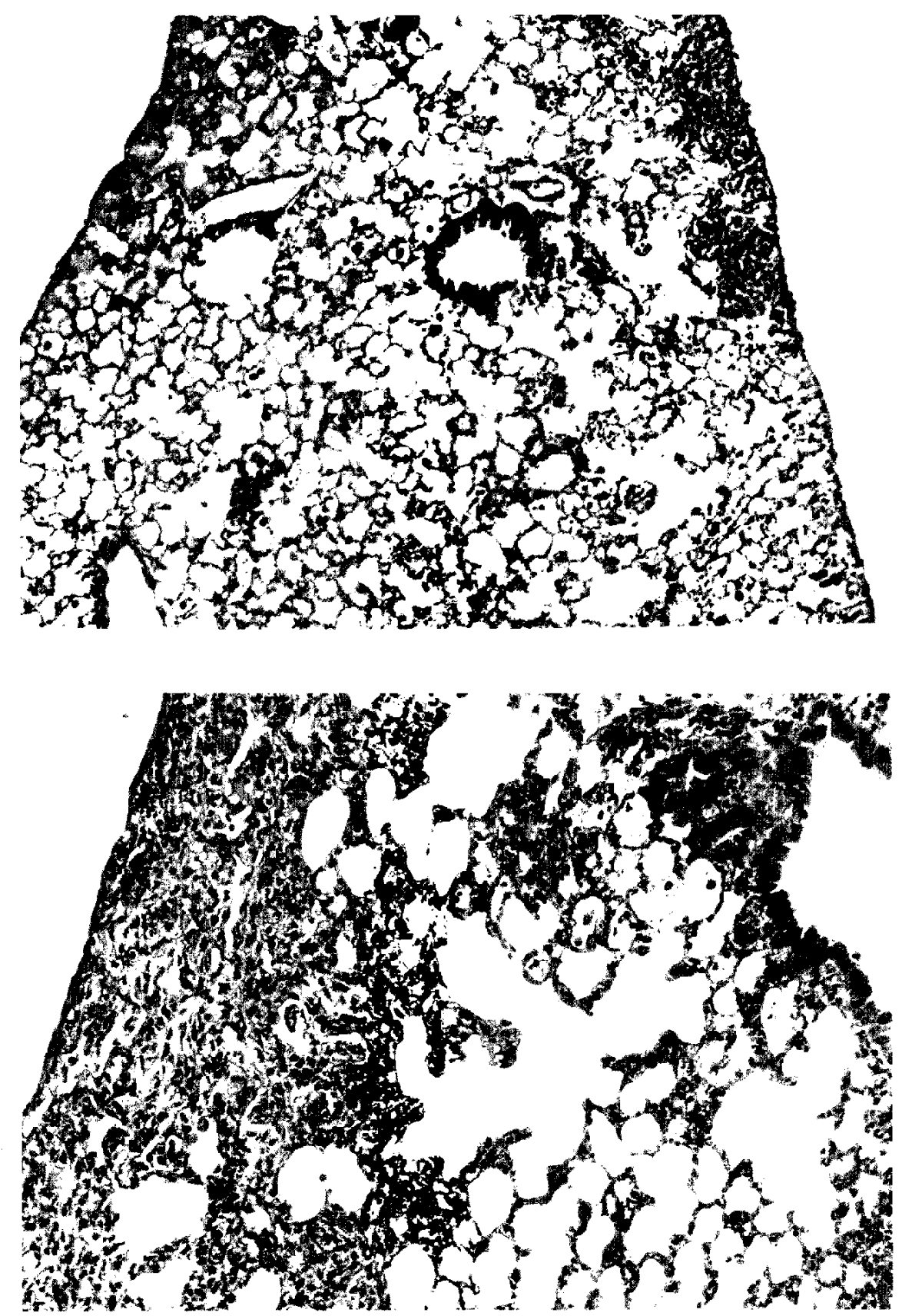

Fig. 2. Histological pictures of the lung in ICR mice 7 and 28 days after the bleomycin (BLM) instillation. See the legend to Fig. 1 for the experimental protocol. Typical of 7-8 specimens. Upper: 7 days after (Hematoxylin-cosin staining, $\times 25$ ). Lower: 28 days after (Hematoxylin-eosin staining, $\times 50$ ).

given to mice p.o. throughout the experimental period starting with the day of BLM instillation. Tranilast suppressed significantly the hydrogen peroxide production under PMA stimulation. The production without PMA stimulation was also suppressed significantly on day 18 by the treatment with tranilast.
Effect of tranilast on the development of pulmonary fibrosis in BLM-instilled mice

Tranilast was given p.o. every day for 35 days in doses of 10 and $20 \mathrm{mg} / \mathrm{kg}$ starting with the day of BLM instillation. The mice were killed the day after the final treatment with tranilast (Fig. 6). The HP content in the right lung of mice instilled with BLM (control) increased significantly compared with that in mice instilled with saline. Tranilast at both doses significantly suppressed the BLM-induced 
Saline

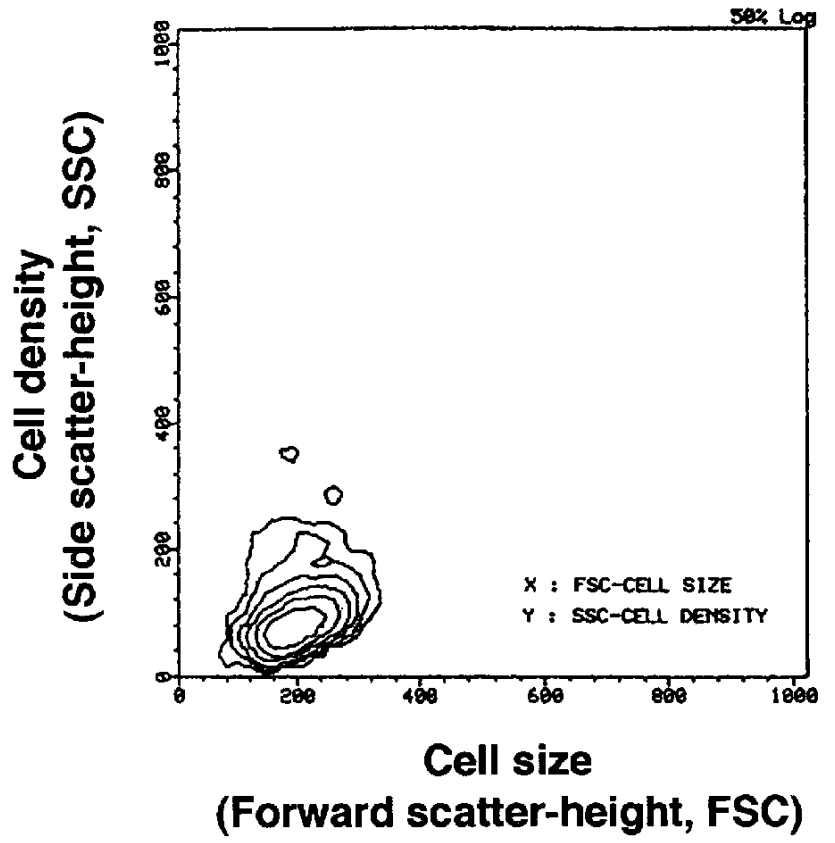

BLM

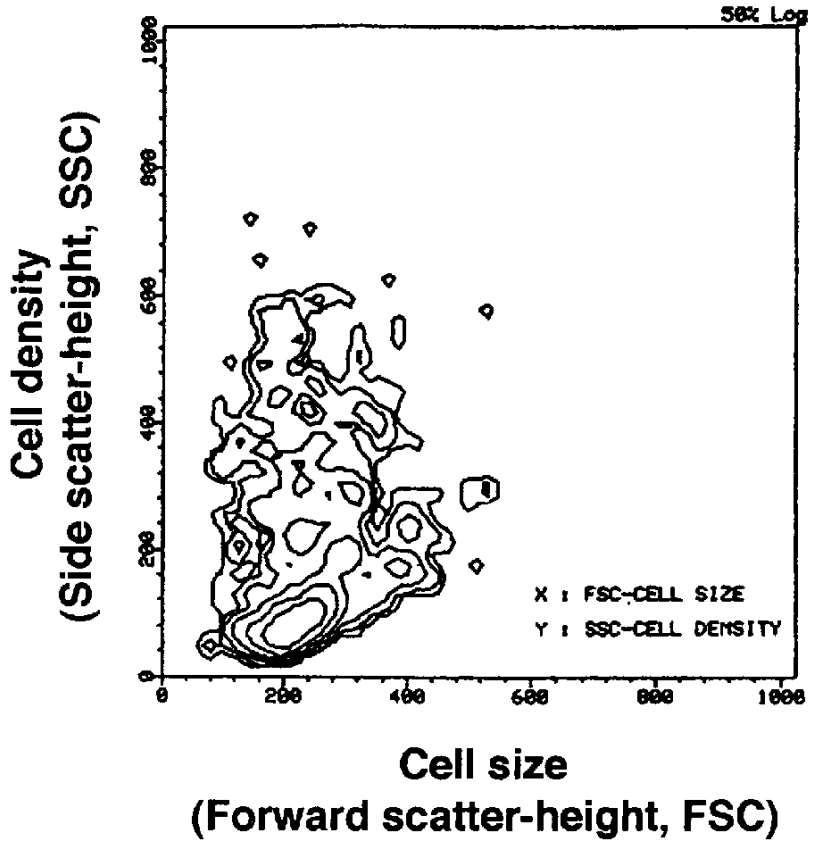

Fig. 3. Comparative distribution of cell size (FSC) and cell density (SSC) of MAC-1 ${ }^{\dagger}$ cells recovered from lung tissue of ICR mice at 18 days after the bleomycin (BLM) instillation. Mice were given BLM intratracheally at a dose of $0.01 \mathrm{mg} / \mathrm{mouse}$ on day 0 . The assay was carried out using FACS can. The data were analyzed by the LYSIS II program.
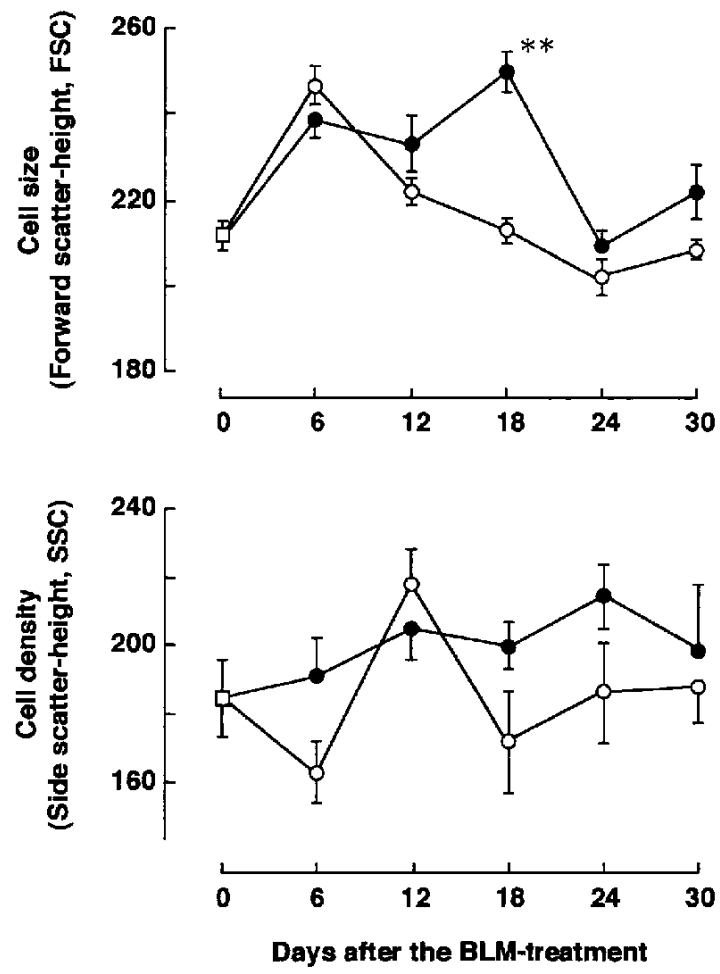

Fig. 4. Cell size (mean FSC) and cell density (mean SSC) of MAC$1^{+}$cells recovered from lung tissue of ICR mice at varying times after the bleomycin (BLM) instillation. See the legend to Fig. 3 for the experimental protocol. Each point represents the mean \pm S.E.M. of 4 to 8 mice. ${ }^{* *}$ : Statistically significant difference from the corresponding saline group at $\mathrm{P}<0.01$. 二 : Normal, $\bigcirc$ : Saline, BLM.

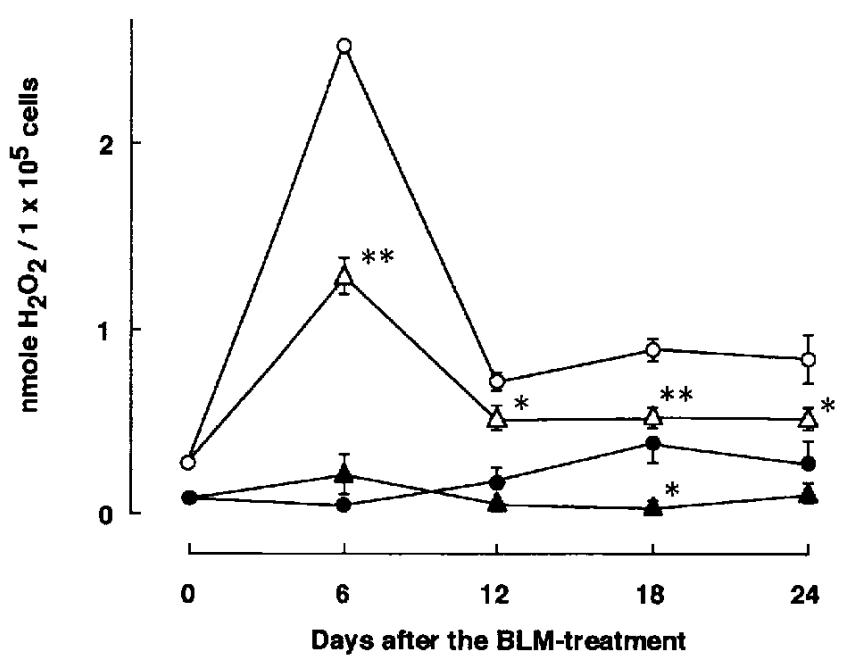

Fig. 5. Effect of tranilast on hydrogen peroxide production from alveolar macrophages (AM) in ICR mice instilled with bleomycin (BLM) intratracheally. Mice were given BLM intratracheally at a dose of $0.01 \mathrm{mg} /$ mouse on day 0 . Tranilast $(20 \mathrm{mg} / \mathrm{kg})$ was given p.o. every day consecutively starting with the day of the BLM instillation. AM obtained from more than 13 mice were pooled in each group and incubated with $(\bigcirc, \triangle)$ or without phorbol myristate acetate (PMA) $(\boldsymbol{O}, \boldsymbol{\Delta})$ for $90 \mathrm{~min}$ at $37^{\circ} \mathrm{C} . \bigcirc$, Control, $\wedge, \mathbf{\Delta}$ : Tranilast. Each point represents the mean \pm S.E.M. of 3 to 6 wells. ${ }^{* * * *}$ : Statistically significant difference from the control at $\mathrm{P}<0.05$ and $\mathrm{P}<0.01$, respectively. 


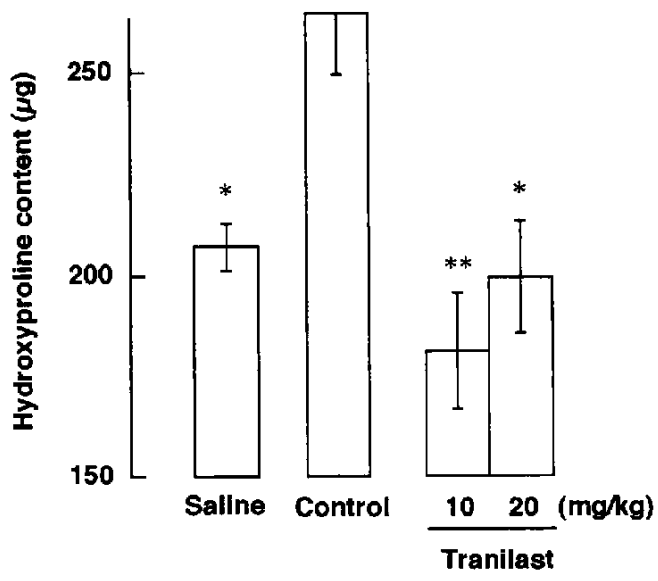

Fig. 6. Effect of tranilast on hydroxyproline content in right lung of ICR mice instilled with bleomycin (BLM) intratracheally. Mice were given BLM at a dose of $0.01 \mathrm{mg} /$ mouse on day 0 . Tranilast was given p.o. in doses of 10 and $20 \mathrm{mg} / \mathrm{kg}$ every day consecutively for 35 days starting with the day of the BLM instillation. Mice were killed 35 days after the BLM instillation. Each column represents the mean \pm S.E.M. of 6 to 8 mice. ${ }^{*} * *$ : Statistically significant difference from the control at $\mathbf{P}<0.05$ and $P<0.01$, respectively.

increase of HP content to the level of that seen in the saline mice. In histological examinations of left lung sections stained with HE or by the Azan-Mallory method, the lungs of mice treated with tranilast were less affected by fibrosis than those of the control mice, although lungs of the control mice were affected by fibrosis to varying degrees from animal to animal, even from section to section. There were no apparent differences in histopathological changes including migrated cellular elements between mice treated with $10 \mathrm{mg} / \mathrm{kg}$ and $20 \mathrm{mg} / \mathrm{kg}$ of tranilast.

Effect of tranilast on the production of hydrogen peroxide from murine peritoneal macrophages

Tranilast added to the medium of the peritoneal macrophages at the time of stimulation with PMA suppressed the hydrogen peroxide production in a dose-dependent fashion $(100-300 \mu \mathrm{M})$ (Fig. 7). The opsonized zymosan stimulated the peritoneal macrophages to produce hydrogen peroxide only in the presence of $\mathrm{Ca}^{2+}$. Tranilast suppressed hydrogen peroxide production from the cells that had been stimulated with the opsonized zymosan (Fig. 8).

Effect of various anti-oxidant agents on the development of the pulmonary fibrosis in BLM-instilled mice

To clarify whether reactive oxygen species are involved in the development of BLM-induced pulmonary fibrosis, we examined the effect of various anti-oxidant agents on BLM-induced pulmonary fibrosis in ICR mice. The drugs used were as follows: Allopurinol, CV-3611, KB-5666, DMSO, DMTU and Vt-E. They were given every day

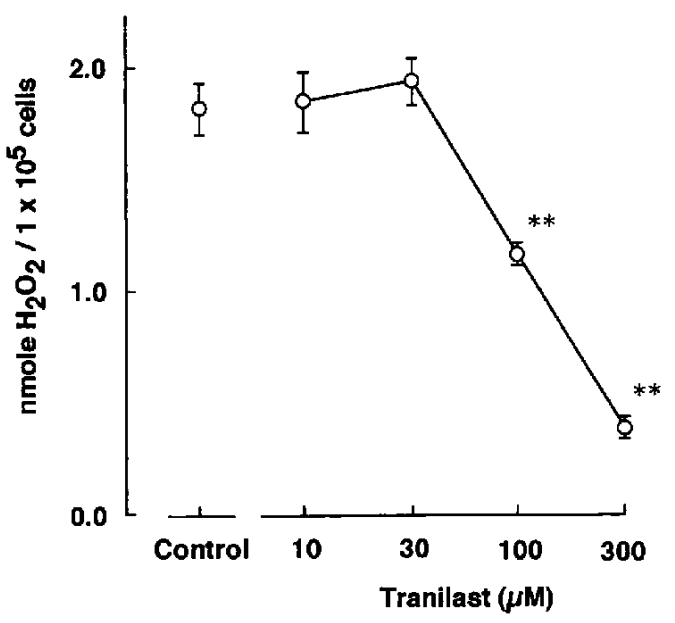

Fig. 7. Effect of tranilast on hydrogen peroxide production from phorbol myristate acetate (PMA)-stimulated peritoneal macrophages (PM). PM were incubated with PMA and various concentrations of tranilast for $90 \mathrm{~min}$ at $37^{\circ} \mathrm{C}$. Each point represents the mean \pm S.E.M. of 6 wells. ${ }^{* *}$ : Statistically significant difference from the control at $\mathrm{P}<0.01$.

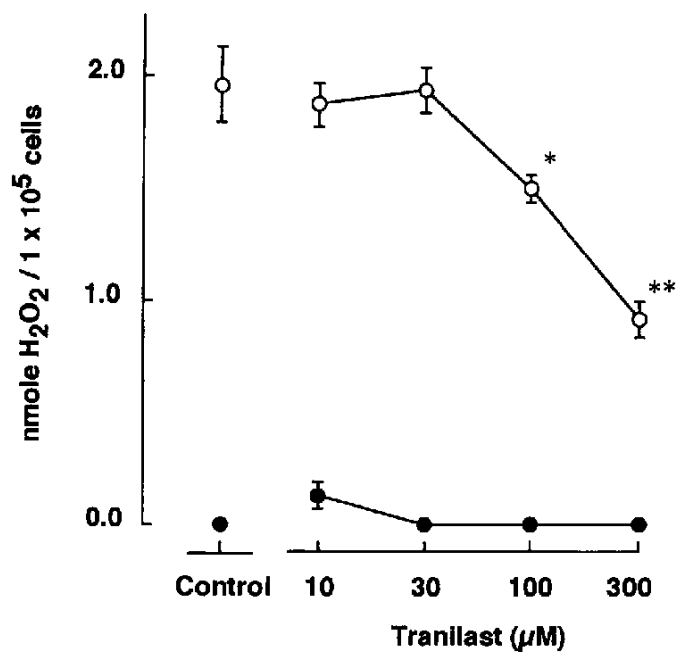

Fig. 8. Effect of tranilast on hydrogen peroxide production from opsonized zymosan-stimulated peritoneal macrophages (PM). PM were incubated with opsonized zymosan and various concentrations of tranilast for $90 \mathrm{~min}$ at $37 \mathrm{C}$. $\mathrm{O}$ : with $\mathrm{Ca}^{2-}$, without $\mathrm{Ca}^{2+}$. Each point represents the mean \pm S.E.M. of 6 wells. ${ }^{* * * *}$ : Statistically significant difference from the control at $\mathrm{P}<0.05$ and $\mathrm{P}<0.01$, respectively.

throughout the experimental periods starting with the day of BLM instillation. Allopurinol, CV-3611, KB-5666 and DMTU were given p.o. for 30 days at doses of 2 to 50 $\mathrm{mg} / \mathrm{kg}$. DMSO and Vt-E were given subcutaneously for 23 days at doses of 100 to $1000 \mathrm{mg} / \mathrm{kg}$. The mice were killed the day after the final drug treatment. Vt-E suppressed the BLM-induced increase of the HP content at 
Table 1. Effects of allopurinol, CV-3611 and KB-5666 on hydroxyproline content in the right lung of ICR mice treated with bleomycin (BLM)

\begin{tabular}{|c|c|c|c|c|c|}
\hline $\begin{array}{l}\text { Treatment } \\
\text { with BLM }\end{array}$ & Drug & $\begin{array}{c}\text { Dose } \\
(\mathrm{mg} / \mathrm{kg})\end{array}$ & $\mathbf{N}$ & $\begin{array}{c}\text { Hydroxyproline } \\
(\mu \mathrm{g})\end{array}$ & $\begin{array}{l}\text { content } \\
(\% \text { Inc) }\end{array}$ \\
\hline \multicolumn{3}{|l|}{ - (Saline) } & 7 & \multicolumn{2}{|l|}{$216.9 \pm 8.4^{* *}$} \\
\hline+ & Control & & 7 & $336.5 \pm 27.6$ & $(100)$ \\
\hline \multirow[t]{4}{*}{+} & Allopurinol & 2 & 7 & $269.1 \pm 21.1$ & (44) \\
\hline & & 5 & 6 & $340.8 \pm 38.7$ & $(104)$ \\
\hline & & 10 & 5 & $347.6 \pm 51.3$ & (109) \\
\hline & & 20 & 5 & $288.1 \pm 30.0$ & $(60)$ \\
\hline- (Saline) & & & 7 & $211.8 \pm 9.9^{* *}$ & \\
\hline+ & Control & & 8 & $336.7 \pm 21.7$ & $(100)$ \\
\hline \multirow[t]{4}{*}{+} & $C V-3611$ & 5 & 7 & $298.4 \pm 19.5$ & (67) \\
\hline & & 10 & 7 & $307.5 \pm 22.4$ & (75) \\
\hline & & 20 & 7 & $288.5 \pm 12.2$ & (58) \\
\hline & & 50 & 6 & $315.0 \pm 25.2$ & (81) \\
\hline- (Saline) & & & 8 & $210.4 \pm 5.2^{*}$ & \\
\hline+ & Control & & 5 & $306.7 \pm 30.4$ & $(100)$ \\
\hline \multirow[t]{3}{*}{+} & KB-5666 & 10 & 7 & $243.3 \pm 16.6$ & (34) \\
\hline & & 20 & 6 & $237.3 \pm 22.7$ & (28) \\
\hline & & 50 & 6 & $270.6 \pm 26.2$ & (63) \\
\hline
\end{tabular}

Mice were given BLM intratracheally at a dose of $0.01 \mathrm{mg} /$ mouse on day 0 . Drugs were given p.o. every day for 30 days starting with the day of the BLM instillation. Each value represents the mean \pm S.E.M. N: Number of mice. \%oInc: Percent of the control increase. ${ }^{*, * *}$ : Statistically significant difference from the control at $\mathrm{P}<0.05$ and $\mathrm{P}<0.01$, respectively.

$100 \mathrm{mg} / \mathrm{kg}$, but not at 200 and $500 \mathrm{mg} / \mathrm{kg}$ (Table 2). KB5666 showed a tendency to suppress it at doses of 10 and $20 \mathrm{mg} / \mathrm{kg}(0.05<\mathrm{P}<0.1)$, but not at $50 \mathrm{mg} / \mathrm{kg}$ (Table 1$)$. The other drugs at any doses did not suppress the increase of the HP content (Tables 1 and 2). None of the drugs affected significantly the BLM-induced increases of wet whole lung weight and dry right lung weight (data not shown), even Vt-E at a dose of $100 \mathrm{mg} / \mathrm{kg}$ (Wet whole lung weight: Normal, $261.2 \pm 25.5 \mathrm{mg}$; Control, $403.3 \pm 40.4 \mathrm{mg} ; 100 \mathrm{mg} / \mathrm{kg}$ Vt-E, 361.6 $\pm 46.1 \mathrm{mg}$; Dry right lung weight: Normal, $25.8 \pm 1.9 \mathrm{mg}$; Control, $44.4 \pm 4.6 \mathrm{mg} ; 100 \mathrm{mg} / \mathrm{kg} \mathrm{Vt}-\mathrm{E}, 38.1 \pm 5.3 \mathrm{mg}$; See Table 2 for the number of animals included).

\section{DISCUSSION}

In the biochemical and histopathological examination of lung in the BLM-instilled mice, the lung HP content, an index of collagen accumulation, did not increase 7 days after the instillation, but histologically acute type inflammatory responses were observed. On day 28 , the HP content increased significantly. Histologically, severe
Table 2. Effects of vitamin E, dimethylsulfoxide (DMSO) and dimethylthiourea (DMTU) on hydroxyproline content in the right lung of ICR mice treated with bleomycin (BLM)

\begin{tabular}{llrrrr}
\hline $\begin{array}{l}\text { Treatment } \\
\text { with BLM }\end{array}$ & Drug & $\begin{array}{c}\text { Dose } \\
(\mathrm{mg} / \mathrm{kg})\end{array}$ & $\mathrm{N}$ & \multicolumn{2}{c}{ Hydroxyproline content } \\
$(\mu \mathrm{g})$ & $(\% \mathrm{Onc})$ \\
\hline- (Saline) & & & 8 & $185.6 \pm 9.9^{*}$ & \\
+ & Control & & 8 & $258.8 \pm 21.7$ & $(100)$ \\
+ & Vitamin E & 100 & 7 & $199.5 \pm 13.8^{*}$ & $(19)$ \\
& & 200 & 7 & $307.8 \pm 36.8$ & $(167)$ \\
& & 500 & 6 & $263.5 \pm 18.9$ & $(106)$ \\
\hline- (Saline) & & & 8 & $185.6 \pm 9.9^{*}$ & \\
+ & Control & & 8 & $258.8 \pm 21.7$ & $(100)$ \\
+ & DMSO & 100 & 6 & $265.1 \pm 11.9$ & $(109)$ \\
& & 500 & 7 & $308.2 \pm 33.2$ & $(167)$ \\
& & 1000 & 7 & $273.8 \pm 12.2$ & $(106)$ \\
\hline- (Saline) & & & 6 & $211.9 \pm 6.7^{* *}$ & \\
+ & Control & & 8 & $310.2 \pm 22.2$ & $(100)$ \\
+ & DMTU & 20 & 6 & $314.5 \pm 30.7$ & $(104)$ \\
& & 50 & 4 & $316.0 \pm 51.3$ & $(106)$ \\
& & 100 & 5 & $274.5 \pm 18.0$ & $(64)$ \\
& & 200 & 4 & $322.8 \pm 35.6$ & $(113)$ \\
\hline
\end{tabular}

Mice were given BLM intratracheally at a dose of $0.01 \mathrm{mg} /$ mouse on day 0. Vitamin E and DMSO were given s.c. every day for 23 days, and DMTU was given p.o. every day for 30 days starting with the day of BLM instillation. The mice were killed the day after the final treatment with the respective drug. Each value represents the mean \pm S.E.M. N: Number of mice. $\%$ Inc: Percent of the control increase. ${ }^{* * * *}$ : Statistically significant difference from the control at $\mathrm{P}<0.05$ and $\mathrm{P}<0.01$, respectively.

fibrosis was observed in the lung and the number of foamy AM increased. They filled up many of the alveolar spaces surrounding the fibrotic areas, especially in the subpleural regions.

We then analyzed the size and density of the intraparenchymal AM. In saline-instilled mice, the size and the density of the AM increased on day 6 and day 12, respectively, probably because of a non-specific irritative effect of the instillation. Compared with the changes in saline-instilled mice, the size of the AM in the BLM-instilled mice increased significantly by day 18 . The cell density tended to increase day by day after the BLM instillation, although the density of the cells from BLM-instilled mice on day 12 was lower than that of the cells from saline-instilled mice for an unclear reason. These results suggest that AM was activated, not only in the earlier acute inflammatory phase, but also in the later chronic phase. This is also supported by the activity of AM in BALF to generate hydrogen peroxide. By the instillation of BLM, the activity examined under PMA stimulation increased dramatically on day 6 , and the activity remained at a higher level than normal until the final day of the experiment (day 24). The 
cells that were not stimulated with PMA also showed a higher level of activity in the late phase (days 18 and 24).

Tranilast has long been used clinically for the treatment of allergic diseases because it suppresses chemical mediator release from mast cells. However, as described in the Introduction, it has been suggested recently that tranilast suppresses not only the activation of mast cells but also those of monocytes, lymphocytes and leukocytes. The in vivo administration of tranilast suppressed the increases of AM activity to generate hydrogen peroxide and the development of fibrosis (Figs. 5 and 6). Furthermore, tranilast suppressed the generation of reactive oxygen species from murine macrophages in vitro (Figs. 7 and 8 ) in agreement the previous report on human neutrophils (5).

These results suggest that tranilast suppresses BLMinduced pulmonary fibrosis by inhibiting the activation of AM. It is possible, however, that another mechanism causes tranilast to suppress BLM-induced fibrosis, because of its radical scavenger activity (18). If the reactive oxygen species produced by the activated AM is essential for the induction of pulmonary fibrosis, tranilast might suppress the fibrosis by scavenging the reactive oxygen species. Wang et al. reported that administration of taurine partially reduced lung fibrosis induced with BLM in hamsters (22). This amino acid appeared to have antioxidant and membrane-stabilizing properties $(23,24)$. Experiments in animals also showed that exposure to air having an elevated concentration of oxygen increased the development of BLM-induced fibrosis (25), while hypoxia decreased it (26). In addition, it is reported (27) that the cytotoxicity of BLM is due to DNA breakage caused by the generation of superoxide free radicals in the presence of iron (II). As we have reported (8), however, tranilast does not suppress the tumorcidal activity of BLM in vivo and in vitro. To evaluate the role of reactive oxygen species in the development of fibrosis, we examined the effect of anti-oxidant agents on BLM-induced pulmonary fibrosis in mice. DMSO and DMTU act as free radical scavengers (28). It has been reported that CV-3611 and $\alpha$ tocopherol protect against reactive oxygen species-mediated damage that occurs as a consequence of ischemic reperfusion (29). KB-5666 has been reported to inhibit lipid peroxidation (30). Allopurinol is well known for its inhibition of xanthine oxidase (31). None of them affected the increases of wet and dry lung weights in mice instilled with BLM. Vt-E at $100 \mathrm{mg} / \mathrm{kg}$ suppressed the increase of lung HP content by BLM, and KB-5666 at 10 and 20 $\mathrm{mg} / \mathrm{kg}$ showed a tendency to suppress it. However, there was no dose-dependency in the effects of Vt-E and KB5666. The other agents did not suppress the increase of the HP content. Considering these together, it is likely that an anti-oxidant agent does not effectively suppress the BLM-induced fibrosis, and tranilast suppresses fibro- sis by inhibiting macrophage activation but not by scavenging the produced reactive oxygen species. In this experiment, we did not use superoxide dismutase as an antioxidant because it was not certain that the enzyme given intravenously could act as a radical scavenger in the extravascular event in the lung.

Recently, there are several clinical reports which state that tranilast shows a curative or preventive effect on skin keloids and hypertrophic scars (32). It is reported that TGF- $\beta$ produced by skin fibroblasts in the wound healing process (33) stimulates themselves to synthesize collagen (34) and other proteins composing the extracellular matrix (35). Suzawa et al. demonstrated by using a carrageenin-induced granuloma model in rats that tranilast suppressed fibroblast collagen synthesis by inhibiting $T G F-\beta_{1}$ and prostaglandin $E_{2}$ production from inflammatory cells and inhibited fibroblast proliferation by inhibiting the IL-1 production (36). In addition, by using human keloids or hypertrophic scar fibroblasts transplanted into nude mice, they demonstrated that tranilast suppresses collagen synthesis of the fibroblasts through suppressing the TGF- $\beta_{1}$ release from the fibroblasts themselves (37).

There are also many reports $(14,38)$ claiming that TGF- $\beta$ plays an important role in the development of lung fibrosis. Even though corticosteroids are the standard therapeutic agents for human fibrotic lung diseases, most patients with idiopathic pulmonary fibrosis do not respond to this treatment. According to Khalil et al. (38), this is because corticosteroids suppress the influx of macrophages into the lungs of rats during the early inflammatory process caused by BLM, but have little effect on the secretion of TGF- $\beta_{1}$ by the AM. They emphasized that corticosteroids suppressed the production of IL-1 and TNF but did not suppress the production of TGF- $\beta_{1}$ from AM, suggesting that TGF- $\beta_{1}$ plays an essential role in the development of BLM-induced pulmonary fibrosis.

From the results described here, it is clear that tranilast suppresses BLM-induced AM activation. The suppression may result in the reduced production of TGF- $\beta$ from the AM and the suppression of fibrosis. In a further experiment, we are planning to examine the effect of tranilast on the TGF- $\beta_{1}$ production from the AM of mice instilled with BLM.

In conclusion, tranilast suppresses BLM-induced pulmonary fibrosis as shown in this and previous papers $(7$, 8), probably by inhibiting the activation of the AM. Tranilast can be expected to be of value as a therapeutic agent for the disease.

\section{REFERENCES}

1 Crooke ST and Brander WT: Bleomycin, a review. J Med 7, $333-427$ (1976) 
2 Snider GL, Celli BR, Goldstein RH, O'Brien JJ and Lucy EC: Chronic interstitial pulmonary fibrosis produced in hamsters by endotracheal bleomycin. Am J Respir Dis 117, 289-297 (1978)

3 Giri SN: Pharmacologic perspectives in pulmonary fibrosis research. In Focus on Pulmonary Pharmacology and Toxicology, Edited by Hollinger MA, Vol 2, pp 19-55, Boca Raton, Florida (1990)

4 Koda A, Kurashina Y and Nakazawa M: The inhibition mechanism of histamine release by $N$-(3,4-dimethoxycinnamoyl)-anthranilic acid. Int Arch Allergy Appl Immunol 77, 244-245 (1985)

5 Miyachi Y, Imamura S and Niwa Y: The effect of tranilast of the generation of reactive oxygen species. J Pharmacobiodyn 10, 255-259 (1987)

6 Komatsu H, Kojima M, Tsutsumi N, Hamano S, Kusawa H, Ujiie A, Ikeda $S$ and Nakazawa M: Mechanism of inhibitory action of tranilast on the release of slow reacting substance of anaphylaxis (SRS-A) in vitro: Effect of tranilast on the release of arachidonic acid and its metabolites. Jpn J Pharmacol 46, $53-60$ (1988)

7 Uesugi Y, Mori H and Kawada K: Role of mast cell in bleomycin-induced pulmonary fibrosis. II. Effect of anti-allergic drugs and pulmonary fibrosis in mast cell deficient mouse, $\mathrm{WBB} \mathrm{F}_{1^{-}}$ $\mathrm{W} / \mathrm{W}^{\vee}$ mouse. Acta Scholae Medicinalis Universitatis Gifu 37, 901-910 (1989) (Abstr in English)

8 Mori H, Kawada K, Peng Zhang, Uesugi Y, Sakamoto O and Koda A: Bleomycin-induced pulmonary fibrosis in genetically mast cell-deficient $\mathrm{WBB} 6 \mathrm{~F}_{1}-\mathrm{W} / \mathrm{W}^{\mathrm{v}}$ mice and mechanism of the suppressive effect of tranilast, an antiallergic drug inhibiting mediator release from mast cells, on fibrosis. Int Arch Allergy Appl Immunol 95, 195-201 (1991)

9 Burkhardt A and Cottier H: Alveolitis and collapse in the pathogenesis of pulmonary fibrosis. Virchows Arch [B] 58, 1-13 (1989)

10 Chandler DB, Hyde DM and Giri SN: Morphometric estimates of infiltrative cellular changes during the development of bleomycin-induced pulmonary fibrosis. Am J Pathol 112, $170-177$ (1983)

11 Haley PJ, Muggenburg DN, Weissman DN and Bice DE: Comparative morphology and morphometry of alveolar macrophages from six species. Am J Anat 191, $401-407$ (1991)

12 Jordana M, Richards C, Irving LB and Gauldie J: Spontaneous in vitro release of alveolar-macrophage cytokines after the intratracheal instillation of bleomycin in rats. Characterization and kinetic studies. Am Rev Respir Dis 137, 1135-1140 (1988)

13 Martinet Y, William NR, Grotendorst GR, Martin GR and Crystal RG: Eagerated spontaneous release of platelet derived growth factor by alveolar macrophage from patients with idiopathic pulmonary fibrosis. N Engl J Med 317, 202209 (1987)

14 Bachwick PR, Lynch JP, Larrick J, Spegloe M and Kunkel SL: Tumor necrosis factor stimulates interleukin-1 and prostaglandin $E_{2}$ production in resting macrophages. Am $J$ Pathol 125 , $421-425$ (1986)

15 Khalil N, Bereznay O, Sporn MB and Greenberg AH: Macrophage production of transforming growth factor- $\beta$ and fibroblast collagen synthesis in chronic pulmonary inflammation. $\mathbf{J}$ Exp Med 170, 727-737 (1989)

16 Denholm EM: Continuous secretion of monocyte chemotactic factors and fibroblast growth factors by alveolar macrophages following a single exposure to bleomycin in vitro. Am J Pathol 141, 965-971 (1992)

17 Yanagi T, Watanabe M, Fukuda S and Tsuji Y: Suppressive effects of tranilast on human mononuclear cells. Jpn J Inflam 7 , $169-173$ (1987) (Abstr in English)

18 Kihara $H$, Nagata $S$, Matsuura $T$, Sogawa $H$, Teshima $H$ and Ago Y: Tranilast inhibits superoxide production by human neutrophils. J Clin Exp Med (Igaku no Ayumi) 142, 775-776 (1987) (Abstr in English)

19 Kivirikko KI, Laitinen $O$ and Prockop DJ: Modifications of a specific assay for hydroxyproline in urine. Anal Biochem 19 , 249-255 (1967)

20 Abraham E, Freitas AA and Coutinho AA: Purification and characterization of intraparenchymal lung lymphocytes. J Immunol 144, 2117-2122 (1990)

21 Pick E and Mizel D: Rapid microassays for the measurement of superoxide and hydrogen peroxide production by macrophages in culture using an automatic enzyme immunoassay reader. $\mathbf{J}$ Immunol Methods 46, 211-226 (1981)

22 Wang Q, Giri SN, Hyde DM and Nakashima JM: Effect of taurine on bleomycin-induced pulmonary fibrosis in hamsters. Proc Soc Exp Biol Med 190, 330-338 (1989)

23 Wright CE, Tallan HH, Lin YY and Gaull GE: Taurine: Biological update. Annu Rev Biochem 55, 427-453 (1986)

24 Huxtable RJ: From heart to hypothesis: A mechanism for the calcium modulatory actions of taurine. Adv Exp Med Biol 217, $371-387$ (1987)

25 Tryka AF, Skornik WA, Godleski JJ and Brain JD: Potentiation of bleomycin-induced lung injury by exposure to $70 \%$ oxygen. Am Rev Respir Dis 126, 1074-1079 (1982)

26 Brend N: Protective effect of hypoxia on bleomycin lung toxicity in the rat. Am Rev Respir Dis 130, $307-308$ (1984)

27 Kuramochi $H$, Takahashi K, Takita $T$ and Umezawa H: An active intermediate formed in the reaction of bleomycin-Fe(II) complex with oxgen. J Antibiot 34, 576-582 (1981)

28 Fox RB, Harada RN, Tate RM and Repine JE: Prevention of thiourea-induced pulmonary edema by hydroxy-radical scavengers. J Appl Physiol 55, 1456-1459 (1983)

29 Tanabe $M$ and Kito G: Effects of CV-3611, a new free radical scavenger, on ischemic heart failure in conscious beagle dogs. Jpn J Pharmacol 50, 467-476 (1989)

30 Hara H, Kogure K, Kato H, Ozaki A and Sukamoto T: Amelioration of brain damage after focal ischemia in the rat by a novel inhibitor of lipid peroxidation. Eur J Pharmacol 197, 75-82 (1991)

31 Feigelson P, Davidson JD and Robins RK: Pyrazolo-pyrimidines as inhibitors and substrates of xanthine oxidase. J Biol Chem 226, 993-1000 (1957)

32 Waseda T, Arai K, Sato T, Sekine R, Sato S and Fujita K: The effect of tranilast for the treatment of hypertrophic scar and keloid. Ther Res 1, 155-159 (1984) (Abstr in English)

33 Hayashi K, Frangich G, Wolfe G and Kenyon KR: Expression of transforming growth factor- $\hat{\beta}$ in wound healing of vitamin A-deficient rat corneas. Invest Ophthalmol Vis Sci 30, 239-247 (1989)

34 Ignotz RA and Massague J: Transforming growth factor- $\bar{\beta}$ stimulates the expression of fibronectin and collagen and their incorporation into the extracellular matrix. J Biol Chem 261, $4337-4345$ (1986)

35 Border WA and Ruoslahti E: Transforming growth factor- $\beta$ in 
disease: the dark side of tissue repair. J Clin Invest 90, 1-7 (1992)

36 Suzawa $\mathbf{H}$, Kikuchi S, Ichikawa $\mathrm{K}$ and Koda A: Inhibitory action of tranilast, an anti-allergic drug, on the release of cytokines and $\mathrm{PGE}_{2}$ from human monocytes-macrophages. Jpn J Pharmacol 60, 85-90 (1992)

37 Suzawa H, Kikuchi S, Arai N and Koda A: The mechanism in- volved in the inhibitory action of tranilast on collagen biosynthesis of keroid fibroblasts. Jpn J Pharmacol 60, 91 -96 (1992)

38 Khalil N, Whitman C, Li Z, Danielpour D and Greenberg A: Regulation of alveolar macrophage transforming factor- $\beta$ secretion by corticosteroids in bleomycin-induced pulmonary inflammation in rat. J Clin Invest 92, 1812-1818 (1993) 